\title{
Case Comment: Secrets and Lives - The Public Safety Exception to Solicitor-Client Privilege: Smith V. Jones
}

\author{
WAYNE N. RENKE
}

Smith v. Jones ${ }^{1}$ confirms what we already knew but were reluctant to have exposed to public view. The rules of solicitor-client privilege and professional confidentiality begin with the assurance that information provided by a client to counsel and those working for counsel shall not be disclosed without the consent of the client. This basic assurance, though, is subject to qualifications. In particular, the "public safety" exception to privilege and confidentiality arises when the information provided by the client supports the inference that the client is a danger to the life or bodily integrity of an innocent third party. While the exception has long found expression in our codes of professional conduct, we must feel a certain discomfort with the advertisement in a Supreme Court judgment that we are leaky vessels for secrets; and that some of the darkest secrets, the secrets clients would most want kept private, are those susceptible to disclosure.

What is novel in Smith v. Jones is the application of the public safety exception in circumstances established outside the confines of a law school professional responsibility class. What is distressing about Smith v. Jones is the failure of the Supreme Court to take the opportunity to deal fully with the principles, policies, and procedures bearing on the disclosure of privileged information for public safety purposes. In Smith v. Jones, the Supreme Court has produced only a rough outline of issues, without rigorous analysis, without a discussion of the implications of the decision, and without offering much practical guidance. The decision is correct in general principle and arguably correct on the evidence, but is more likely to vex than help those wrestling with difficult disclosure issues.

I will (I) review the facts of the case and the lower court decisions, (II) discuss the Supreme Court's decision and reasons, and (III) point out some issues left dangling.

\section{FACTS AND LOWER COURT DECISIONS ${ }^{2}$}

Smith v. Jones arose from a Vancouver criminal prosecution. "Jones" was charged with aggravated sexual assault, respecting an incident that occurred on 14 September 1996. The complainant was a prostitute who worked Vancouver's downtown Eastside,

Associate Professor of Law, University of Alberta, Edmonton, Alberta.

Smith v. Jones (1999), 169 D.L.R. (4th) 385, 132 C.C.C. (3d) 225 (S.C.C.) [hereinafter Smith v. Jones, cited to C.C.C.]. A version of this paper was presented to the Canadian Bar Association, Alberta Branch (Northern) Health Law Section on 4 May 1999. Thanks are extended to the Section members for their comments.

2 The following incorporates facts set out in the trial and appeal decisions not mentioned in the Supreme Court reasons.

' Smith v. Jones, supra note 1 at 253. 
a "skid row" area. ${ }^{4}$ Jones allegedly hired the complainant, assaulted her, and attempted to tie her up; he was interrupted by passers-by and fled. ${ }^{5}$ On 17 September 1996, after hearing on the radio that the police were searching for the perpetrator, he turned himself in. ${ }^{6}$ Jones remained in custody until 19 December 1996, when he was released on bail. A condition of bail was that Jones refrain from visiting the Eastside, although he later admitted that he continued to visit this area. ${ }^{7}$ Otherwise, Jones was neither charged with nor, apparently, suspected of having committed any further offences. $\mathrm{He}$ had no prior record. ${ }^{8}$

In the course of trial preparations, defence counsel referred Jones to "Dr. Smith," an experienced forensic psychiatrist retained by counsel. ${ }^{9}$ The purpose of the referral was to obtain psychiatric opinion evidence relevant to a potential defence or to sentencing. Jones was advised by counsel that his communications with Dr. Smith were protected by solicitor-client privilege. Anything Jones said to Dr. Smith could not be disclosed without Jones' consent. ${ }^{10}$

On 30 July 1997, Jones and Dr. Smith had a ninety minute interview. Jones was "cooperative" and "disarmingly candid." "Jones provided detailed information concerning the offence and its planning. He indicated that he had deliberately selected a suitable prostitute as a victim; he had brought duct tape and a rope to restrain her; he intended to mutilate her body to prevent identification; he had prepared the basement of his home for the killing and mutilation; he had prepared his home to avoid interruptions; he had scheduled his vacation to facilitate the commission of the offence; and he had developed plans for the disposal of the body. ${ }^{12}$ Furthermore, he planned to kill other prostitutes. The first victim was to be a "trial run" to determine if he could "live with" what he had done. ${ }^{13}$

Jones related his sexual fantasies to Dr. Smith. Commencing at puberty, Jones had rape fantasies. His violent ideations progressively developed and worsened toward fantasies of torture and murder. ${ }^{14}$ In his 20 s, Jones began to hire prostitutes from Vancouver's skid row area to engage in sadistic activities. The assault for which he was charged, however, was the first time that he engaged in violence with an "unwilling" woman; it was the first time that he attempted to act out his deepest and most extreme

Smith v. Jones, [1998] B.C.J. No. 3182 at para. 5 (C.A.), online: QL (B.C.J.) [hereinafter Smith v. Jones (C.A.)].

Smith v. Jones, [1997] B.C.J. No. 3136 at para. 2 (S.C.), online: QL (B.C.J.) [hereinafter Smith v. Jones (S.C.)].

Smith v. Jones (C.A.), supra note 4 at para. 5.

Smith v. Jones, supra note 1 at 253; Smith v. Jones (S.C.), supra note 5 at para. 11; Jones went so far as to change his vehicle's licence plates to avoid police detection during his forbidden visits. "Public Safety and Private Communications: Keeping up with the Jones" Kapoor's Criminal Appeals Review, Issue 1 (7 May 1999) at para. 2, online: QL (V.C.A.R.).

Smith v. Jones (S.C.), supra note 5 at para. 3.

Smith v. Jones, supra note 1 at 238; Smith v. Jones (S.C.), supra note 5 at para. 3.

Smith v. Jones (C.A.), supra note 4 at para. 7; Smith v. Jones (S.C.), supra note 5 at para. 12.

Smith v. Jones, supra note 1 at 238; Smith v. Jones (S.C.), supra note 5 at paras. 6, 7.

Smith v. Jones, supra note 1 at 238; Smith v. Jones (S.C.), supra note 5 at para. 7.

Smith v. Jones (S.C.), supra note 5 at para. 8; Smith v. Jones (C.A.), supra note 4 at para. 7. 
fantasies. ${ }^{15}$ Jones told Dr. Smith that his sadistic fantasies persisted. Jones himself was concerned about what he might do next. ${ }^{16}$

The interview alarmed Dr. Smith. Dr. Smith formed the opinion that Jones suffered a "[paraphilic] disorder with multiple paraphilias (in particular, sexual sadism), personality disorder with mixed features, and some antisocial features and drug abuse difficulty." Jones needed treatment, including medication, to reduce his sexual drive. $^{18}$

The next day, on 31 July 1997, Dr. Smith contacted defence counsel and advised that, in his opinion, Jones was dangerous, and that unless Jones received treatment, it was "more likely than not" that he would act out his fantasies of kidnapping, torturing, and killing women. ${ }^{19}$

Defence counsel chose not to tender Dr. Smith's opinions as evidence. Defence and Crown counsel made a deal. On 24 September 1997, Jones pled guilty to the reduced charge of aggravated assault (i.e., reduced from aggravated sexual assault). The Crown recommended a sentence of two years less a day with a lengthy probation period, which would include counselling for Jones. ${ }^{20}$ Sentencing was initially set for 19 November 1997 , to allow for the preparation of a pre-sentence report but was later adjourned to 15 December 1997.21

On or about 19 November 1997 (after the guilty plea was entered but before sentencing), Dr. Smith contacted defence counsel and learned that his concerns would not be communicated to a judge. Dr. Smith thereupon commenced the action with which we are concerned, in which he sought from the British Columbia Supreme Court a declaration entitling him to disclose information obtained from Jones. ${ }^{22} \mathrm{Dr}$. Smith's application was supported by an affidavit setting out, inter alia, the communications made to him by Jones and Dr. Smith's psychiatric opinions about Jones. ${ }^{23}$ Jones defended and counter-claimed, on the basis that Dr. Smith was prohibited by solicitorclient privilege or solicitor's work brief privilege from disclosing that either Dr. Smith was retained by the defence or any communications between Jones and Dr. Smith. ${ }^{24}$ Jones filed an affidavit in response. He deposed to a strong desire to obtain counselling, provided some reasons for his failure to take counselling in the past (in particular, his

Smith v. Jones (S.C.), supra note 5 at para. 9; Smith v. Jones (C.A.), supra note 4 at para. 7. "Willingness" to engage in sado-masochistic activities has been held not to amount to "consent" for criminal law purposes, and so is no bar to the establishment of the actus reus for assault offences: R. v. Welch (1995), 25 O.R. (3d) 665 (C.A.); R. v. Brown, [1993] 2 All E.R. 75 (H.L.). Smith v. Jones (S.C.), supra note 5 at paras. 11, 12.

Smith v. Jones, supra note 1 at 252; Smith v. Jones (S.C.), supra note 5 at para. 13; Smith v. Jones (C.A.), supra note 4 at para. 7.

Smith v. Jones (S.C.), supra note 5 at para. 13; Smith v. Jones (C.A.), supra note 4 at para. 7. Smith v. Jones, supra note 1 at 238-39; Smith v. Jones (S.C.), supra note 5 at para. 13.

Smith v. Jones (C.A.), supra note 4 at para. 9.

Smith v. Jones, supra note 1 at 239.

lbid. at 239 and 254.

Ibid. at 239.

Smith v. Jones (C.A.), supra note 4 at paras. 9, 10. 
fear that obtaining counselling would aggravate his eventual sentence), but took issue with only a few statements attributed to him by Dr. Smith. ${ }^{25}$ Jones swore that he no longer had any intentions of doing harm. ${ }^{26}$

The hearing was held before Henderson J. To protect privilege, Henderson J. granted leave for the use of pseudonyms (hence the "Smith" and "Jones"), heard the matter in camera, and sealed the court file. ${ }^{27}$ Where Jones' account of his communications to Dr. Smith differed from Dr. Smith's, Henderson J. accepted Dr. Smith's version. ${ }^{28}$ Henderson J. ruled that certain materials in Dr. Smith's affidavit were irrelevant or had only minimal probative value, and so edited them out. ${ }^{29}$ Henderson J. held that, in the circumstances, public safety considerations not only permitted Dr. Smith to disclose the remaining information, but imposed on Dr. Smith a duty to disclose the information to the police and the Crown:

I see no utility in an order which merely permits Dr. Smith to disclose what he has been told. Where a psychiatrist has concluded that his patient presents an imminent danger to the life or safety of another person, what circumstances could justify an exercise of discretion against disclosing $-I$ know of none.... I find that disclosure by Dr. Smith is not only permissible, but mandatory in these circumstances. ${ }^{30}$

Subsequently, Henderson J. stayed his order to allow an appeal. ${ }^{31}$ A condition of the stay was that Jones surrender himself into custody, which he did, and where he remains. ${ }^{32}$

Jones appealed. The British Columbia Court of Appeal allowed the appeal only to the extent that Dr. Smith was held not to have a duty to disclose but only a discretion to disclose (the mandatory order to disclose was changed to a permission to disclose). The basis for reversing this aspect of Henderson J.'s order was jurisdictional, rather than substantive. The Court of Appeal's view was that the authority of a court to grant a declaration of rights did not include the authority to impose duties:

[Henderson J.'s] conclusion, with respect, overlooks the limitations upon the powers of the court under Rule 5(22), which confers the power to make declaratory orders. That is a broad power but does not extend to requiring the plaintiff to do that which the court has declared he has the right to do. ${ }^{33}$

Thus, the Court of Appeal did not decide that a duty to report could never be found. It left open the possibility that, in appropriate factual and jurisdictional circumstances, a court may recognize a duty to report. The Court of Appeal directed that Henderson

Smith v. Jones, supra note 1 at 253.

Smith v. Jones (C.A.), supra note 4 at para. 27.

Smith v. Jones, supra note 1 at 255 ; Smith v. Jones (S.C.), supra note 5 at paras. $38,39$.

Smith v. Jones (S.C.), supra note 5 at para. 14.

Smith v. Jones, supra note 1 at 255.

Simith v. Jones (S.C.), supra note 5 at para. 35.

Smith v. Jones, supra note I at 239.

Smith v. Jones (C.A.), supra note 4 at para. 12; Smith v. Jones, supra note 1 at 253.

Smith v. Jones (C.A.), supra note 4 at para. 30. 
J.'s orders respecting the use of pseudonyms, the holding of proceedings in camera, and the sealing of the court file remain in place pending further orders. ${ }^{34}$ The Court of Appeal stayed its order to permit Jones to file a further appeal. ${ }^{35}$

Jones' sentencing on the aggravated charge was again adjourned to await the outcome of a further appeal.

\section{The Decision of The Supreme Court of Canada: Discussion}

Jones appealed to the Supreme Court of Canada. He applied for an order that the appeal be heard in camera. This application was denied, but a publication ban was imposed pending the decision on the main issue. ${ }^{36}$ The majority of the Supreme Court dismissed Jones' appeal. Cory J. wrote for the majority, joined by L'Heureux-Dubé, Gonthier, McLachlin, Iacobucci, and Bastarache JJ. Major J., joined by Lamer C.J.C. and Binnie J., dissented. The majority and dissent agreed on the facts, on most of the applicable principles, and, generally, on the application of the principles to the facts. The majority affirmed Henderson J.'s ruling, as varied by the Court of Appeal, permitting disclosure of both Dr. Smith's opinions and the communications from Jones supporting those opinions. ${ }^{37}$ The dissent too would have allowed disclosure of Dr. Smith's opinions and of the fact that Jones consulted with Dr. Smith, but not disclosure of the supporting communications from Jones to Dr. Smith. ${ }^{38}$ In the result, Cory J. directed that the file be unsealed and that the publication ban be removed. ${ }^{39}$

The Supreme Court's decision raises six sets of issues - (A) the framework for considering limitations on solicitor-client privilege; (B) the interests at stake; (C) interests supporting the limitation of privilege and confidentiality; (D) whether disclosure is mandatory or discretionary; (E) justifiable means for limiting privilege and confidentiality; and $(F)$ the application of the public safety exception to the facts of the case.

\section{A. FramewORK}

Setting out and discussing the Court's reasons is made difficult by the failure of both the majority and the dissent to establish an explicit analytical framework for considering the availability of a purported exception to solicitor-client privilege. Major $\mathrm{J}$. did allude to an appropriate framework late in his reasons through his reference to Oakes, ${ }^{40}$ but that was too little too late. ${ }^{41}$

\footnotetext{
$34 \quad$ Ibid. at para. 32.

$35 \quad$ Ibid. and Smith v. Jones, supra note 1 at 239.

36. Smith v. Jones, supra note 1 at 256.

$37 \quad$ Jbid. at 254 and 256.

$38 \quad$ Ibid. at 237

39 Ibid. at 256.

40 R. v. Oakes, [1986] I S.C.R. 103 [hereinafter Oakes].

4 Smith v. Jones, supra note 1 at 236.
} 
The starting point for developing the framework is our liberal commitment to the "dignity and worth of the human person." ${ }^{2}$ This commitment entails, in part, that individuals cannot be treated as mere means to others' ends. An individual's interests deserve consideration, and the individual should be entitled to pursue his or her interests without interference - unless the interference can be justified. In a society in which everyone is equal before and under the law, each individual's dignity and worth must be respected. The interests of individuals affected by law may differ. Sometimes (as in the case of the public safety exception to privilege) the difficulty for the law lies in working out solutions where different individuals have different interests at stake, and the circumstances will not permit all of those interests to be satisfied. ${ }^{43}$ In such cases, legal rules are arrived at through a balancing of the inconsistent interests. Balancing has four aspects: the legal recognition of relevant interests of one individual or set of individuals (the interests at stake); the acknowledgment of a threat posed to those interests by a legal rule; the legal recognition of competing interests of other individuals (the competing interests); and the process or method of developing a response that promotes both sets of interests to the greatest extent possible and achieves the solution to the conflict that is best in the circumstances. The clearest description of the mechanics of balancing in our jurisprudence was given by Dickson J., as he then was, in the Oakes case (as "touched up" by subsequent decisions). ${ }^{44}$ Given that a set of interests has been recognized as warranting constitutional protection under the Canadian Charter of Rights and Freedoms ${ }^{45}$ and that a particular piece of legislation has been found to limit or to be contrary to those interests, the legislation may be justified under s. 1 of the Charter if the following conditions are satisfied:

(a) the legislation must promote a "pressing and substantial objective";

(b) the means of promoting the objective employed by the legislation must be "rationally connected" to the objective; be "minimally intrusive," or "minimally impair" other rights and freedoms; and

have salutary effects that outweigh the means' deleterious effects.

Reference Re Section 94(2) of the Motor Vehicle Act, R.S.B.C. 1979, [1985] 2 S.C.R. 486 at 503, Lamer $\mathrm{J}$.

A presupposition of the law is that we are able to make comparisons between the interests affected - not merely between numbers of individuals affected, but between the relative importance of their interests.

Oakes, supra note 40 at 138-39; see also R. v. Laba, [1994] 3 S.C.R. 965 at 1006-11, Sopinka J.; and Dagenais v. Canadian Broadcasting Corp., [1994] 3 S.C.R. 835 at 888-89, Lamer C.J.C.

Canadian Charter of Rights and Freedoms, Part I of the Constitution Act, 1982, being Schedule B to the Canada Act 1982 (U.K.), 1982, c. II [hereinafter the Charter]. Section 1 reads as follows: "The Canadian Charter of Rights and Freedoms guarantees the rights and freedoms set out in it subject only to such reasonable limits prescribed by law as can be demonstrably justified in a free and democratic society." 
The Oakes approach is the appropriate framework for analyzing the limitation of clients' interests in confidentiality. In this context, the first step is the identification of the interests at stake and the threat posed to them by the public safety exception; the second step is the identification of the competing interests served by the public safety exception; and the third step is the determination of whether the public safety exception rule properly balances the interests at stake and the competing interests. Indeed, Dickson J. demonstrated the suitability of this approach in the pre-Oakes case of Solosky v. R., ${ }^{46}$ in which he employed an Oakes-like framework for determining the limitations on solicitor-client privilege in a prison environment.

\section{B. INTERESTS AT STAKE}

On one level, the interests at stake are clear enough. Cory J. set out the "argument from complexity": The complexity of the administration of justice entails that clients have the right to professional assistance to defend themselves appropriately. Without confidentiality protections, clients would not provide full disclosure to counsel and, without full disclosure, counsel would not be able to provide the best possible advice. ${ }^{47}$ This is an "instrumental" justification of solicitor-client privilege. Given legal complexity, privilege is a means of (an instrument for) securing good representation. A feature of this argument, noted by Luban, is that privilege is understood to benefit the administration of justice, rather than the client. ${ }^{48}$ This understanding is evident in Cory J.'s judgment. He described the privilege as "fundamentally important to our judicial system"; 49 as "essential if sound legal advice is to be given in every field";

(1979), 50 C.C.C. (2d) 495 at 511 (S.C.C.), Dickson J.:

"[T] he Court is placed in the position of having to balance the public interest in maintaining the safety and security of a penal institution, its staff and its inmates, with the interest represented by insulating the solicitor-client relationship. Even giving full recognition to the right of an inmate to correspond freely with his legal adviser, and the need for minimum derogation therefrom, the scale must ultimately come down in favour of the public interest. But the interference must be no greater than is essential to the maintenance of security and the rehabilitation of the inmate."

Smith v. Jones, supra note 1 at 240,241 . Major J. also offered this argument from complexity: ibid. at 230-31. Indeed, the argument from complexity appears to have become the official Supreme Court justification for privilege. It was repeated in the recent $R$. v. Campbell case ([1999] S.C.J. No. 16, online: QL (S.C.J.)). Binnie J., writing for the court, declared that:

[S]olicitor-client privilege is based on the functional needs of the administration of justice. The legal system, complicated as it is, calls for professional expertise. Access to justice is compromised where legal advice is unavailable. It is of great importance, therefore, that the RCMP be able to obtain professional legal advice in connection with criminal investigations without the chilling effect of potential disclosure of their confidences in subsequent proceedings.

(Ibid. at para. 49.) For similar instrumental views in the U. S. context, see C.B. Mueller \& L.C. Kirkpatrick, Evidence (Boston: Little Brown, 1995) at 358-59; J.W. Hall Jr., Professional Responsibility of the Criminal Lawyer (Rochester, New York: Lawyers Co-operative Publishing, 1987) at 266-68; and J.M. Burkoff, Criminal Defence Ethics: Law and Liability, rev. ed. (St. Paul, Minnesota: West Group, 1998) at 6-48. 
as "an element that is both integral and extremely important to the functioning of the legal system";" and as "a principle of fundamental importance to the administration of justice." 52 The instrumental justification may serve well enough, but it has two weaknesses. First, it is founded on institutional interests rather than individual interests. Second, if institutional interests change or develop new emphases (e.g. an emphasis on full disclosure by all parties to promote the truth-finding aspect of litigation), the instrumental importance of privilege may decline. These weaknesses dispose the instrumental justification to entertain exceptions to privilege and prevent the justification from solidly resisting the erosion of privilege.

Major J. gestured toward a more secure base for solicitor-client privilege. He put the privilege on virtually a constitutional footing. In his view, at least in the criminal context, "principles embodied in the rules of privilege have gained constitutional protection by virtue of the enshrinement of the right to full answer and defence, the right to counsel, the right against self-incrimination and the presumption of innocence in ss. 7, 10(b) and 11(d) of the Canadian Charter of Rights and Freedoms...." ${ }^{53}$ The denial of solicitor-client privilege would, practically, frustrate these rights. ${ }^{54}$ Cory $\mathrm{J}$. did not lend his authority to these views.

Major J. also directed us to deeper levels of principle. He quoted the following key passage from Lamer C.J.C.'s decision in $R$. v. M.B.P. ${ }^{\text {ss }}$ (without developing its implications fully, and without connecting it to the justification of the recognition of privilege itself): "Perhaps the single most important organizing principle in criminal law is the right of an accused not to be forced into assisting in his or her own prosecution...."s6 In M.B.P., Lamer C.J.C. commented that "the presumption of innocence and the power imbalance between the state and the individual are at the root of this principle." ${ }^{77}$ The presumption of innocence entails, in part, that the state has the burden of accumulating and presenting sufficient evidence to prove, beyond a reasonable doubt, that the accused is guilty; the state must accumulate and present this evidence through its own resources, without compelling the accused to participate in incriminating himself or herself. Put another way, an accused should have the choice to cooperate with the authorities or not. The interests at stake are not only the interests in full answer and defence addressed by the instrumental argument, but also the interests in the institutional arrangements that separate the roles of prosecution and defence.

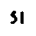

52

Ibid.

Ibid. at 241.

Ibid. at 231.

Ibid. at 231; see Mueller \& Kirkpatrick, supra note 47 at 36I: "The attorney-client privilege has constitutional underpinnings. The defendant's right to counsel in criminal cases, guaranteed by the Sixth Amendment and most state constitutions, would appear to require some degree of confidentiality for communications between a defendant and his attomey" [footnotes omitted]. (1994), 89 C.C.C. (3d) 289 (S.C.C.) [hereinafter M.B.P.]; see also $R$ v. Jones (1994), 89 C.C.C. (3d) 353 at 367 , Lamer C.J.C. (dissenting).

M.P.B., ibid. at 304.

Ibid. 
The presumption of innocence does not merely bring us to the institutional separation between the state and the accused. It also returns us to the dignity and worth of the individual. As Dickson J. wrote in Oakes,

[t]he presumption of innocence protects the fundamental liberty and human dignity of any and every person accused by the State of criminal conduct.... It ensures that until the State proves an accused's guilt beyond all reasonable doubt, he or she is innocent.... The presumption of innocence confirms our faith in humankind; it reflects our belief that individuals are decent and law-abiding members of the community until proven otherwise. $^{58}$

In Luban's words,

[h]uman dignity requires that, if a person is accused of a crime but denies her guilt, that denial should be assumed to be in good faith until proven otherwise. To assume that the denial is in good faith is to assume that the accused has a story to tell or a case to make.... A defence, however, is not easy to present, even if it exists ... the advocate tells the defendant's story as the defendant would if she only knew the law and had the skills. Understood in this light, advocacy is indeed a noble calling: it gives voice to the legally mute. Thus, human dignity requires that the defendant have such an advocate."

Solicitor-client privilege protects human dignity by protecting the right to counsel. The privilege ensures that clients can provide full and frank disclosure to counsel and obtain the best defence consistent with their presumed innocence. It also protects human dignity by protecting clients' choice to talk to the authorities or not.

The public safety exception to solicitor-client privilege threatens the interests protected by privilege, regardless of the asserted basis of privilege. It threatens instrumental interests, since clients who fear disclosure of their dangerousness might well be deterred from communicating freely with their legal advisors, thereby diminishing the capacity of their advisors to assist them, resulting in weaker cases, and ultimately impairing the administration of justice. It threatens institutional separation of interests: if a lawyer bound by solicitor-client privilege may break confidence and provide inculpatory evidence based on communications from a client to the authorities, the client's right to choose not to cooperate is subverted; the client is, in effect, forced to participate in his or her own prosecution. His or her words are taken to the authorities without his or her consent. Breaking privilege transforms counsel into cop. The exception also threatens the dignity of the accused. As with instrumental interests, if the client is deterred from confiding in counsel, the client loses the ability to defend himself or herself properly. The presumption of innocence is thereby impaired. As with institutional interests, if the client's words are repeated back against him or her, the client's choice of confidentiality is subverted, in violation of his or her dignity. To use the client's words to promote interests other than those selected by the client is to treat the client not as an entity worthy of dignity and respect, but as a means to others' ends. It therefore must be seen whether the interferences with privilege entailed by the public safety exception can be justified. 


\section{COMPETING INTERESTS}

The public safety exception to solicitor-client privilege also rests on individuals' dignity and worth. Section 7 of the Charter confirms that we each have the rights to life, liberty, and security of the person. The public safety exception to privilege promotes the important objectives of preserving life and bodily integrity through authorizing steps that reduce risks to them. The preservation of life and bodily integrity are objectives that warrant the limitation of solicitor-client privilege. ${ }^{60}$ As a matter of principle, according priority to the promotion of life and bodily integrity over the promotion of privilege makes sense. A key purpose of social order is the promotion of the good of each member of society. A social order should promote at least the lives and physical well-being of members. Privilege does not directly contribute to this end. Privilege plays a role in the protection of individual interests and in the advancement of the administration of justice, which in turn promote, in part, the lives and well-being of members of society. Privilege is a means of achieving ends; the promotion of life and physical integrity has more the character of an end or a basic social objective. Privilege is intrinsically subordinated to the promotion of life and bodily integrity.

Nevertheless, more than the mere suggestion, intimation, or possibility of death or serious bodily harm must exist before privilege may be overridden. The public safety exception depends on risk assessment. The majority and dissent agreed on the factors that a lawyer must consider in assessing whether risks exist that warrant reduction: "First, is there a clear risk to an identifiable person or group of persons? Second, is there a risk of serious bodily harm or death? Third, is the danger imminent?" ${ }^{61}$ Cory J. correctly pointed out that the factors "often overlap and vary in their importance and significance." ${ }^{12}$ Even with this caution, Cory J. oversimplified.

The following factors should be considered in a public safety exception risk analysis:

\section{SOURCE OF RISK}

Obviously, the source of the risk must be identified. This goes without saying, which explains why Cory J. did not say it. It should nonetheless be borne in mind: the mere fact that even serious and imminent risks exist does not warrant overriding privilege unless there is a risk that the particular client in question is a risk, a likely cause of the feared consequences. We should not focus so much on the consequences that we forget the need to tie the client to those consequences. the lawyer should reveal information necessary to save a life" (M.H. Freedman, Lawyers' Ethics in an Adversary System (Indianapolis: Bobbs-Merrill, 1975) at 6). 


\section{PERSONS AT RISK}

A risk must be a risk for an individual or identifiable group of individuals, although "identifiability" should be interpreted broadly. Cory J. held that "as a general rule a group or person must be ascertainable." ${ }^{63}$ According to Cory J., the size of the group is a relevant consideration. Cory J. suggested that, ordinarily, the greater the size of the group, the less pressing the risk, although there is no "cut off" group size and group size is not a determinative consideration: "a general threat of death or violence directed to everyone in a city or a community, or anyone with whom the person may come into contact, may be too vague to warrant setting aside the privilege." ${ }^{64}$ Then again, if a person has access to biological weapons, a target population of the size of a city or a province would not be "too large" to permit a recognition of a pressing threat. Furthermore, if a client said that he or she would kill someone that day, even a person he or she would randomly select, and if the threat were otherwise judged serious, some action designed to block the client's plans could be justified.

The "persons at risk" factor should not be overemphasized in the privilege context. It is a factor that would have more weight in determining whether a lawyer was liable in tort - the size and specificity of the potential victim group would be relevant to whether the lawyer owed a duty of care to members of the group. Cory J. was clear that he was not establishing tort rules; ${ }^{65}$ nonetheless, his reliance on tort cases seems to have led him to over-stress this factor. ${ }^{66}$

\section{MAGNITUDE OF THE RISK}

Not every risk warrants setting aside privilege. The risk must be of sufficiently serious harm. The Supreme Court suggested that only risks of death or serious bodily harm including serious psychological harm $^{67}$ warrant overriding privilege. An element of non-trivial violence is necessary. ${ }^{68}$ Death and bodily harm are neither vague nor overbroad descriptions of events. Death, in most cases, is clear and precise. Bodily harm has long been interpreted without difficulty in the criminal law, as in cases of assault causing bodily harm or criminal negligence causing bodily harm. ${ }^{69}$ Despite Cory J.'s occasional reference to risks of future "crimes" and despite the lack of elaboration, his decision does not limit the public safety exception to risks of behaviour classifiable as criminal. The feared action may be criminal, tortious, in violation of regulatory standards, or possibly even legal: the issue is whether the action is likely to

\footnotetext{
Ibid. at 249.

Ibid. at 250.

Ibid. at 244.

Ibid. at 244-46, and see the text accompanying note 92 infra.

Ibid. at 250, citing $R$ v. McCraw, [1991] 3 S.C.R. 72 for the proposition that serious psychological harm may constitute serious bodily harm.

Ibid. at 250.

69 See ss. 2 (definition of "bodily harm"), 267(b) (assault causing bodily harm), 269 (unlawfully causing bodily harm) and 221 (criminal negligence causing bodily harm) of the Criminal Code, R.S.C. 1985, c. C-46 [hereinafter the Criminal Code].
} 
result in death or serious bodily harm; the issue is whether there is "danger to public safety."70

An aspect of relevant risk hinted at by references to future crimes is the moral unjustifiability of the risk posed. Suppose that a client had been repeatedly attacked by a third party, and the client had suffered serious injury. If the client threatened to use proportional force, with or without an intention to cause death, to repel yet another attack (i.e., if the client threatened to act in justifiable self-defence), disclosure would appear not to be attracted. For the risk to engage the exception, the potential victim or victims must be, in a relevant sense, innocent. The exception should not be used to alert an assassin to defensive tactics. The interests supporting the exception would not be served if the exception were employed as a means of sacrificing the client.

Neither Cory nor Major JJ. gave any serious consideration to whether threats of consequences other than death or serious bodily harm would justify disclosure. Cory $\mathrm{J}$. did assert that contemplated crimes of fraud, counterfeiting, or the sale of stolen goods, for example, would not engage the exception." Suppose that a client (without asking for any relevant legal advice) gave counsel reason to believe that the client would seriously disrupt the computer system of a major university, leading to the virtual shut down of the teaching and research of the institution for several months; that the client would destroy all data preserved by stock exchanges; that the client would flood Canada with counterfeit $\$ 20$ bills; or that the client would import very large quantities of illegal drugs into Canada: would these threats support disclosure? These actions would be crimes, but they involve no violence, or at least no direct violence. Cory and Major JJ. gave us no guidance.

\section{TIME LINE FOR MATERIALIZATION OF RISK: "IMMINENCE"}

Cory J. stated that "there must be a sense of urgency." $72 \mathrm{He}$ did not impose any particular time limit on risks. An imminent risk (a risk that may materialize in the next few moments) may engage the public safety exception; a risk that will not materialize for several years may also do so if the nature of the risk is sufficiently serious and definite. ${ }^{73}$ A difficulty with this factor is that Cory J. confused it with other factors. He expressly equated "imminent risk" with "serious risk" of "serious bodily harm."74 This confused timing with both the probability of harm and the nature of harm.

Smith v. Jones, supra note 1 at 248 ; Luban, supra note 48 at 215 . What, it might be wondered, distinguishes the public safety exception from the "criminal communications" exception to privilege? The latter exception permits the disclosure of communications that are in themselves criminal or communications that are made to obtain legal advice to facilitate criminal activities: Smith v. Jones, supra note 1 at 243 . The public safety exception concerns communications that may be neither criminal nor made to obtain advice to commit crimes; the communications support inferences about future injurious acts. The communications might, in fact, expressly concern only past events - from which a likelihood of future injurious behaviour could be inferred. 
Presumably, what an "imminence" factor imports is a judgment that the risk currently exists; there is a "present danger," not a danger or risk or threat of harm that will arise at a future date.

\section{PROBABILITY}

A factor not explicitly discussed by Cory $J$. is the probability of the threatened risk becoming a reality (although he did hint at this factor by his reference to "a serious risk" of "serious bodily harm"). A risk with a low likelihood of materializing may not justify overriding privilege; a risk with a high likelihood of materializing may. Even a low probability of risk may require extraordinary action if the nature of the risk is particularly serious; and even a high probability of risk may not require extraordinary action if the nature of the risk is not particularly serious. A focus on probability reminds us again of the need to link the client and the risk. We should not be so overwhelmed by the fear of consequences that we limit a particular client's confidentiality interests where the risk actually posed by that client is negligible.

The probability factor draws with it the issue of the "standard of proof." A lawyer confronted with the possibility of disclosing privileged information should not be burdened with distinctions between various standards of proof, but should be given some guidance on level of satisfaction that he or she must have before disclosing confidential information. Cory J. did speak of a "clear" risk. Yet, in the course of his review of the evidence in the case, he seemed to abandon even this inexact standard of "clear" evidence in favour of a much lower standard of "some evidence": "Let us assume that the evidence as to imminence of the danger may not be as clear as might be desired. Nonetheless, there is some evidence of imminence." "s "Some evidence" suggests the mere existence of evidence on a point, with no regard to the weight of that evidence. As Jones' counsel argued before the Court of Appeal, many criminal accuseds present "some evidence" of dangerousness. ${ }^{76}$ Cory J. would have done better to require a simple finding that the risk is "likely" or "probable."

\section{PERSPECTIVE}

By whose lights should risk be assessed? Should a lawyer's subjective assessment suffice, or should a lawyer strive to view the circumstances as would the "reasonable person"? The latter perspective is appropriate, hard as it may be to adopt in circumstances calling for quick and difficult action. Clients should not be left to the peculiar sensitivities of individual lawyers. Cory J. could have dealt with both this and the previous issue by requiring, as a prerequisite to disclosure, the existence of

Jones' counsel made this point before the Court of Appeal: "Mr. Mackoff submits [that] the court must recognize that many criminal accused are potentially dangerous persons and [the court] must not allow some possible element of danger to erode the sanctity of the solicitor/client privilege" (Smith v. Jones (C.A.), supra note 4 at para. 26). 
"reasonable and probable grounds" for belief that a client poses a risk of killing or causing serious bodily harm to some other individual.

The foregoing review of risk assessment factors should lead neither to the exaggeration nor to minimization of the complexity of risk assessment. Risk assessment does have many aspects. One might think that no lawyer, faced with the need to make a crucial decision in what may be urgent circumstances, could adequately address and balance the various relevant factors. Analysis, one might suggest, leads only to paralysis, to an inability to judge danger. Yet we can and do make risk assessments, assessments of dangerousness, in our daily lives. ${ }^{78}$ The point of the analysis of risk assessment is to set out the factors that we frequently do, more or less intuitively, consider when assessing risk. A description of the aspects of risk analysis should not induce paralysis, but should ensure that risk assessments are rational. The description operates as a sort of checklist to be consulted to make sure that important factors have not been forgotten.

Risk assessment should not be regarded as too easy: trained psychiatrists have difficulty predicting dangerousness to any higher level of accuracy than lay people; predictions of dangerousness bear a substantial risk of incorrectly labeling individuals as dangerous. ${ }^{79}$ In some cases, dangerousness may be obvious. Lawyers, though, are not trained psychiatrists, they do not have any special training in predicting dangerousness, and they should not be quick to judge dangerousness on the basis of subtle signs.

\section{MUST OR MAY?}

One might argue that if a lawyer is confronted by proof that a client poses a risk to the lives or bodily integrity of others, the lawyer must disclose the relevant evidence to reduce the risk. If others' lives or safety are threatened, no further balancing is required - disclosure of relevant information becomes automatic, dictated by law; more precisely, the issue ceases to be whether information should be disclosed, but only what information should be disclosed and how it should be disclosed. This is the sentiment behind mandatory reporting rules, such as Rule 8(c) of Chapter 7 of the

I recognize that the old "reasonable and probable grounds" language has been largely replaced in the criminal law context with the phrase "reasonable grounds." In Baron v. Canada (1993), 78 C.C.C. (3d) 510 at 531 (S.C.C.), Sopinka J. wrote that "[i]n my view nothing turns on the omission of the word 'probable' ... I respectfully disagree with Locke J.A.'s holding ... that 'reasonable' is not the same as 'reasonable and probable'." With the introduction of R.S.C. 1985, most of the references in the Criminal Code to "reasonable and probable grounds" were replaced by references to "reasonable grounds." The view of the Statutory Revision Committee was that this would not change the law. The virtue of the old language, though, was that it distinguished between the standard of proof that must be satisfied (probability, as opposed to either possibility or proof beyond a reasonable doubt), and the perspective from which proof is assessed (reasonableness, the standard of the reasonable person, as opposed to a subjective perspective). Sec G. de Becker, The Gift of Fear (New York: Dell Publishing, 1997).

79 See R. v. Lyons, [1987] 2 S.C.R. 309 at 367, La Forest J.; $R$. v. Neve (29 June 1999) (Alta. C.A.) at para. 183ff per curiam (Fraser C.J.A., Conrad and Picard JJ.A.), online: Alberta Courts <www.albertacourts.ab.ca/webpage/jdb/judgements/0629_206.htm> (date accessed: 2 July 1999). 
Alberta Code of Professional Conduct: "[a] lawyer must disclose confidential information when necessary to prevent a crime likely to result in death or bodily harm, and may disclose confidential information when necessary to prevent any other crime." ${ }^{10}$ Henderson $J$. imposed an obligation to report. In his estimation, if a psychiatrist finds that his or her patient presents an imminent danger to the life or safety of another, there are no circumstances that would justify an exercise of discretion against reporting. ${ }^{81}$

One of the most remarkable weaknesses of the decision in Smith v. Jones is the failure of the Supreme Court to address in any decisive way the issue of whether disclosure in public safety circumstances is mandatory or discretionary, required or permitted, an obligation or a licence. On the one hand, Cory J. referred to the Court of Appeal's determination that disclosure was discretionary only, ${ }^{82}$ and "affirmed" the Court of Appeal's order - subject only to the unsealing of the court file - dismissing the appeal. ${ }^{83}$ Cory J. did not discuss the Court of Appeal's reversal of Henderson J.'s mandatory disclosure ruling. At one point, Cory J. seemed to contemplate only discretionary reporting: "In certain circumstances, therefore, when the safety of the public is at risk the solicitor-client privilege may be set aside." 84 He quoted without comment the British Columbia Professional Conduct Handbook, which provides only for discretionary disclosure. ${ }^{85}$ On the other hand, Cory J. gave strong rhetorical indication that disclosure in public safety circumstances is mandatory. He quoted Dickson J.'s decision in the Solosky case, and emphasized the following words in the quotation: "[T] he scale must ultimately come down in favour of the public interest."86 He referred to a "duty to warn." In his summary of the applicable principles, Cory J. wrote that if "the threat to public safety outweighs the need to preserve solicitorclient privilege, then the privilege must be set aside." ${ }^{88}$ In the final line of his application of the principles to the evidence, Cory J. claimed that "solicitor-client privilege must be set aside for the protection of members of the public." 89 Some other remarks of Cory J. are ambiguous. He stated that when death or serious bodily harm are threatened, "the privilege should be set aside." 90 "Should" may mean "must," but

Alberta Code of Professional Conduct (Calgary: Law Society of Alberta, 1995) at 68 [emphasis added].

Smith v. Jones (S.C.), supra note 5 at para. 35. Luban has the same view: "If the only way to prevent [the perpetration of injuries on innocent third parties by a client] is to reveal the confidence, no argument that I can see counts against doing so" (Luban, supra note 48 at 205); "But if a client announces an intention to work over an adversary with a lead pipe, maintaining confidentiality would be dead wrong" (ibid. at 205, note 51).

Smith v. Jones, supra note 1 at 239.

Ibid. at 256.

Ibid. at 243 [emphasis added].

lbid. at 248.

Ibid. at 243.

lbid. at 246.

lbid. at 251 [emphasis added].

Ibid. at 254 [emphasis added]. Major J. used "must" language as well: "I agree with Justice Cory's ... conclusion that the confidentiality of the solicitor-client privilege must, in exceptional circumstances of public safety, yield to the public good" (ibid. at 230).

Ibid. at $237,251$. 
if Cory J. meant "must," he should have said "must." Cory J. also wrote that public safety circumstances "will warrant" setting aside solicitor-client privilege.91 "Warrant" may mean "require," but again, if that was meant, it should have been said. The decision's uncertain language and the terms of the dismissal of the appeal forestall a final answer on the mandatory versus discretionary disclosure issue.

Cory J. compounded the uncertainty with his reliance on American tort cases dealing with a duty to disclose. Chief among these was Tarasoff $\mathrm{v}$. Regents of the University of California ${ }^{92}$ in which Tobriner J. recognized a duty to disclose and tortious liability for failure to disclose: "When a therapist determines, or pursuant to the standards of his profession should determine, that his patient presents a serious danger of violence to another, he incurs an obligation to use reasonable care to protect the intended victim against such danger." ${ }^{93}$ Cory J. went on to describe cases in which Tarasoff was distinguished, on the basis of the foreseeability of injury to the plaintiff/victims and the extension of the duty of care to them. Cory J. should not have gone down the Tarasoff road. As he himself noted, Smith v. Jones was not a torts case. Major J. correctly observed that "[the torts] cases are of limited usefulness, as they do not engage any of the legal and constitutional principles which underlie the solicitor-client privilege." Were that observation not sufficient to dispose of any reference to Tarasoff, it has engendered a large, complex, and controversial jurisprudence to which Cory J. barely even alluded. ${ }^{95}$ Tarasoff has been considered in some Canadian cases, but Cory J. did not refer to these. ${ }^{96}$ Tarasoff is a highly uncertain pivot.

The Tarasoff digression distracted Cory J. from some fundamental issues. Should our law ever impose a duty to disclose to protect third parties, a duty to take steps to rescue? Generally, the common law has set its face against imposing such a duty. ${ }^{97}$

Ibid. at 248-50.

92551 P.2d 334 (Cal. 1976) [hereinafter Tarasof].

9. Ibid. at 340 .

* Smith v. Jones, supra note 1 at 237.

95

For a decade old snapshot of the Tarasoff jurisprudence, see A.R. Felthous, The Psychiatrist's Duty to Warn or Protect (Springfield, Illinois: Charles C. Thomas, 1989).

See Tanner v. Norys, [1980] 4 W.W.R. 33 at 62 (Alta. C.A.), leave to appeal to S.C.C. refused (1980), 33 N.R. 355; Wenden v. Trikha (1991), 116 A.R. 81 at 102-105 (Q.B.), amended (1991), 118 A.R. 319 (Q.B.), additional reasons (1992), 124 A.R. 1, aff d. (1993), 135 A.R. 382 (C.A.), per curiam, leave to appeal to S.C.C. refused (1993), 149 A.R. 160; J. Arboleda-Florez \& M. Copithorne, Menial Health Law and Practice (Calgary: Carswell, 1994) at 4-2 (para. 4.3.1), 4-12 (para. 4.27); R.D. Manes \& M. Silver, The Law of Confidential Communications in Canada (Toronto: Butterworths, 1996) at 32-33.

See L.N. Klar, the Honourable A.M. Linden, J., E.A. Chemiak \& P.W. Kryworuk, eds., Remedies in Tort, vol. 2 (Toronto: Carswell, 1987) "Negligence" at para. 141; and see $R$ v. Dunlop, [1979] 2 S.C.R. 881 at 898 , Dickson J.: "A person is not guilty merely because he is present at the scene of a crime and does nothing to prevent it.... The classic case is the hardened urbanite who stands around in a subway station when an individual is murdered." In contrast, s. 2 of the Quebec Charter of Human Rights and Freedoms, R.S.Q. 1980, c. C-12, provides as follows: "Every person whose life is in peril has a right to assistance. Every person must come to the aid of anyone whose life is in peril either personally or [by] calling for aid, by giving him the necessary and immediate physical assistance, unless it involves danger to himself or a third person, or he had another valid reason." 
Could a duty to disclose to protect third parties be imposed as a matter of professional ethics and as a matter of the law of privilege and confidentiality, without engaging liability in tort for failure to disclose? Do different principles apply in the determination of whether privilege should be overridden and whether tortious liability should be imposed? If so, what are those different principles? If the duty to disclose is not enforceable under tort law, what, if anything, are the consequences or liabilities for a failure to disclose, outside of professional discipline?

Must or may: what is the better view? If each individual's life is an important good, if the right action is action promoting the good, and if we should do what is right (meaning that we have a moral duty to do what is right), at least on a moral level, we should act to promote and preserve others' lives. We have a moral duty to disclose serious danger to others. Does professional status affect this duty? Are professionals entitled, because of their status, to ignore a duty that would bind them as private citizens? Professionals like lawyers, physicians, and psychiatrists do have obligations to keep confidences that are not shared by non-professionals. Those obligations, by themselves, cannot block an obligation to disclose, since protecting life is an objective that may override confidentiality. To claim that professionals should not be compelled to disclose but should have a discretion to disclose or not, even in the face of reasonable and probable grounds for belief that a client will seriously injure or kill an innocent third party, is to claim that there are additional factors, grounds, or considerations that professionals should reflect on before deciding whether or not to disclose. In the context of solicitor-client privilege and confidentiality (ignoring tort issues entirely), what additional considerations are there bearing on disclosure itself, on whether disclosure should be made at all? Henderson J. could see none. There may be further considerations, though. Refraining from disclosure may be rational. We shall see under the next heading that circumstances may exist in which disclosure would be irrational or at least not an overriding obligation. There is a small residual area for the exercise of discretion. Disclosure in public safety circumstances, then, should be mandatory, unless there are good reasons for not making disclosure arising from the particular facts of the case.

\section{E. Means for limiting Privilege and Confidentiality}

In keeping with the Oakes approach, the public safety exception to solicitor-client privilege should allow for disclosure only if disclosure (1) would be rationally connected with the reduction of the risk; (2) would involve as little interference with the privilege as is reasonably possible consistent with the reduction of the risk; and (3) would not have deleterious effects that exceed the good effects associated with the reduction of risk.

\section{RATIONAL CONNECTION}

Disclosure should have some reasonable causal connection to the reduction of the identified risk. As Major J. wrote, "[d]isclosure is justified only when it can actually 
accomplish something in the public interest, such as preventing injury or death." 98 Another risk assessment is involved. The lawyer should determine whether (there are reasonable and probable grounds for believing that) disclosure is likely to reduce the risk, or, alternatively, whether the failure to disclose would maintain or aggravate the risk. Here is where reside the additional considerations supporting the residual discretion not to disclose. Disclosure may be superfluous. The authorities may already have (to the knowledge of the lawyer) sufficient information. One might also suggest that disclosure would be superfluous were there absolutely nothing that disclosure could accomplish, if disclosure could not possibly serve to reduce the risk. Such cases, however, would be exceedingly rare. Disclosure may increase risk by (somehow) goading the client to further violence or (as is more likely) by exposing the lawyer or his or her family or co-workers to violence. Outside of wartime, a legal framework founded on the importance of individuals does not usually demand that one individual sacrifice his or her life for another. Personal sacrifice may be morally superior action, but at least as a matter of law, we should not expect lawyers to put third parties' lives ahead of their own or ahead of the lives of people connected to them. Hence, there may be reasons for not effecting disclosure, despite the risks to others that are apparent.

Even where there are no reasons for not effecting disclosure, disclosure should still have a rational connection to the risk. Disclosure must be made to a person or persons who will likely be in a position to reduce the risk. Causally superfluous, wide-scale public broadcast is generally not warranted. Cory J. indicated that the disclosure might be made to the court, the police, a Crown prosecutor, or a potential victim. As Cory J. pointed out, the identity of the person contacted will depend on the "specific circumstances." ${ }^{.99}$

\section{MINIMAL INTERFERENCE}

Disclosure should only be made of that information which is reasonably required for the reduction of the risk, and disclosure should take place in a manner that minimizes the interference with privilege and confidentiality. The majority and dissent agreed that disclosure should be as limited as possible. ${ }^{100}$ Their commitment to the "minimization principle" confirmed that balancing requires consideration of not only potential victims but also the client. The client's interests are not abandoned once the threshold of identified dangerousness has been passed. To the extent possible, even in disclosure, confidentiality should be preserved.

Both Cory and Major JJ. focused on the content of disclosure, as opposed to the means by which disclosure should be effected. This left a gap in their reasoning. Neither grappled with issues of reasonable disclosure tactics that may be adopted to protect a client's interests. ${ }^{101}$ Neither discussed anonymous warnings or warnings

101 See Burkoff, supra note 47 at 6-102, quoting the American Trial Lawyers Association Code, Supplemental Rule 1.6. 
made through third parties (e.g. through independent counsel). They did not discuss circumstances in which it is appropriate not to refer to the name of the client but only to the type of danger he or she represents. ${ }^{102}$ They did not discuss releasing information to Crown counsel on conditions or undertakings respecting the subsequent use of the information (e.g. the information may be used only for the purposes of protecting potential victims and shall not be referred to or relied on in any manner whatsoever in any litigation involving the client).

On the level of content, usually disclosure of all of the information in "the file" is not warranted. Disclosure should only be made of information relevant to the risk and of information that has probative value in excess of its prejudicial effect. Thus, in Smith v. Jones, material referred to in Dr. Smith's affidavit that was irrelevant to the issue of dangerousness or was of minimal probative value was excised and not made public a determination of Henderson J. confirmed by Cory $\mathrm{J}^{103}$

Major J. raised a significant content disclosure issue, which marks the key point at which the dissent diverged from the majority. Major J. argued that certain types of communications should not be disclosed. Major J. stressed the need to protect clients from being "conscripted" against themselves and would have allowed only professionals' opinions to be disclosed along with the fact that the opinions were based on interviews with clients. Because "[o]ur jurisprudence does not allow the conscription of an accused's own words against him," 104 Major J. would not have permitted the disclosure of "any communication from the accused relating to the circumstances of the offence." 105 Cory J., in contrast, allowed both communications to professionals and opinions based on those communications to be disclosed and approved Dr. Smith's disclosure of both types of information. Cory J. did not address Major J.'s concerns. Implicitly, one might suggest, Cory J. ruled that there should not be a categorical exclusion of types of communications from potential disclosure.

This implicit ruling makes sense. For an opinion to have weight, the grounds for the opinion should be disclosed. If an opinion is offered without grounds, it really amounts to a "trust me" proposition and, to that extent, is not worthy of being taken seriously. In fact, allowing "trust me" expressions of opinion would put clients at great risk. Lawyers and other professionals who lacked adequate grounds for disclosure might offer their groundless opinions and have them acted on. The disclosure of grounds helps

The disclosure of confidential information under the public safety exception is ethically analogous to the disclosure of real evidence counsel receives from a client. We are all aware that the disclosure of real evidence must take place in a sensitive, delicate way, to avoid generating more incriminatory inferences concerning the client than is necessary. A minor literature has arisen respecting this problem. This literature could have been usefully considered in the present context. See Hall, supra note 47 at 341-53; Mueller \& Kirkpatrick, supra note 47 at $416-18$ (s. 5.21); and Burkhoff, supra note 47 at 6-110 to 6-121. 
to ensure that disclosure will be done responsibly. ${ }^{106}$ This is not to say that in all circumstances communications from a client relating to an offence need be disclosed. The question is whether these communications form part of (or are "inextricably intertwined with") the grounds for the opinion. Furthermore, lawyers faced with the difficult issue of whether to break confidence or not, in what may be compressed time horizons, should not be forced to make distinctions between "conscriptive" and nonconscriptive evidence; they may not be able to guess which communications are relevant to an offence.

\section{DELETERIOUS EFFECTS}

Another set of issues discussed by Major J. and ignored by Cory J. concerned the balancing of the good effects of disclosure against the deleterious effects of disclosure on clients and others. A further risk assessment is required.

Major J. examined the dangers to offenders and the public created by allowing the disclosure of self-incriminatory client information. His view was that the possibility of disclosure of this information would deter clients from obtaining psychiatric treatment for fear that information they provided would be used against them. Clients may be harmed by suffering the perpetuation of their illness without treatment. In the words of Major J., "[t]he chilling effect of completely breaching the privilege would have the undesired effect of discouraging those individuals in need of treatment for serious and dangerous conditions from consulting professional help." ${ }^{07}$ Disclosure of selfincriminatory information also increases the risk to the public: "If defence counsel cannot freely refer clients, particularly dangerous ones, to medical or other experts without running a serious risk of privilege being set aside, their response will be not to refer clients until after trial, if at all." ${ }^{108}$ Left undiagnosed, these clients would remain dangerous. ${ }^{109}$

Major J.'s comments have two weaknesses. First, the risks he identified do not have much to do with the scope of disclosure, with whether "conscriptive" evidence is or is not disclosed. It is the fact of disclosure generally, the disclosure of opinions of dangerousness, that would likely deter consultation. Second, Major J.'s comments are speculation. His fears rest on empirical propositions, predictions of what is likely to

Major J.'s position is inconsistent with another position he took respecting a purported distinction between an expert's opinion (not privileged) and the communications on which the opinion is based (privileged) - in the circumstances of this case, the distinction was untenable because of the link between the opinion and the "oral history provided by the accused" (ibid. at 233). But if the opinion and communications are so interconnected that they cannot be distinguished for the purposes of the application of privilege, they are presumably so interconnected that they cannot be distinguished for the purposes of disclosure. The Court of Appeal got this point right: "[T]he weight to be attached to the expert's opinion depends upon the soundness of its factual basis. In this case, that basis comes solely from the oral history given by the defendant to the plaintiff in the course of the interview. Without that history, the opinion would be largely, if not completely, devoid of weight" (Smith v. Jones (C.A.), supra note 4 at para. 25). 
occur. His views should not have been offered solely on the basis of common sense, but on the basis of research that indicates what, in fact, people do, despite the possibility of disclosure. ${ }^{10}$

Nonetheless, weaknesses aside, Major $\mathbf{J}$. raised some significant issues. One might add the further consideration that disclosure undermines counsel's role as the defender of the client, and puts counsel into the position of cop. Disclosure makes counsel put others' interests ahead of the client's interests - but counsel's job is (generally) to put the client's interests first.

These concerns can be adequately addressed. The public safety exception applies only in very rare cases. It does not affect the vast majority of litigants. Privilege has long been subject to a number of exceptions, and client confidence in counsel does not appear to have been eroded. As a matter of precedent, the Supreme Court has been willing to override other privileged relationships, despite the possibilities of damage to the relationships."' If psychiatric and therapeutic relationships may be breached in the interests of justice, solicitor-client relationships can be breached in the interests of life. We would probably all agree on the valuation of injuries: given a loss of innocent life on the one hand, and the violation of a duty of confidentiality on the other hand (all other things being equal), we would probably agree that it is worse to lose life than to lose privilege and that it is better to save life than to save privilege. Generally, it is better that someone live than that another's secrets be kept.

\section{F. Application to the facts}

Was disclosure justified on the evidence in Smith v. Jones? All three levels of court thought so.

A first issue was whether Jones' communications to Dr. Smith were covered by solicitor-client privilege (if no privilege or duty of confidentiality applied, then disclosure would not be problematic). The difficulty with applying this privilege was that the communications were not made directly to counsel but to a third party retained

See $R$. v. R.J.S., [1985] O.J. No. 1047 at para. 5 I (C.A.), Lacourcière J.A., online: QL (O.J.): It seems reasonable to assume that confidentiality is essential to the full and satisfactory maintenance of a relationship between a psychiatrist and the patients in a group therapy session. However, the Crown referred to some academic writing and empirical evidence against the assumption. Reference was made to Shuman and Weiner, The Privilege Study: An Empirical Examination of the Psychotherapist-Patient Privilege (1982), N.C.L. Rev. 893, 926... The article by Professors Shuman and Weiner presents empirical evidence to cast doubt on the theoretical relationship between confidentiality and effective therapy. On the basis of data gathered by means of a questionnaire distributed to a representative cross-section of the population, the authors conclude inter alia that patients are probably not deterred from seeking psychiatric help, hindered from making free disclosure, or caused to prematurely terminate their treatment due to lack of a privilege.

See also Mueller \& Kirkpatrick, supra note 47 at 330-31, notes 5, 6. civil case based on sexual assault); $R$. v. $O^{\prime}$ Connor (1995), 103 C.C.C. (3d) I (S.C.C.) (disclosure of complainant's therapeutic records in a sexual assault case). 
by counsel for the purposes of the litigation. Privilege undoubtedly was attracted but which privilege - solicitor-client, anticipation of litigation, solicitor's work brief, or psychiatrist-client (on a case-by-case basis)? ${ }^{12}$ Cory J. held that it was not necessary to consider the distinctions between the types of privilege because both parties made their submissions on the basis that solicitor-client privilege applied. ${ }^{113}$ Major $\mathrm{J}$. provided a more substantial and useful account of the basis for the application of this privilege. In his opinion, "[t]radition and case law support the extension of [solicitorclient] privilege to include communications, by conversation or otherwise, between the accused and the expert in the same way as the traditional solicitor-client relationship."I4 Major J. supported his opinion with Canadian, Australian, United Kingdom, and American authorities. ${ }^{115}$

Counsel for Dr. Smith apparently argued that while communications to a professional may be privileged, the professional's opinions based on those communications are not; this assertion was supported by the doctrine that there is no property in a witness. ${ }^{116}$ While the majority did not deal with this point, Major J. clearly rejected the argument in the circumstances of the case. At least where the entire evidential basis for a professional's relevant knowledge and opinion stem from privileged communications, the professional's opinions are also privileged. ${ }^{117}$

Since the communications were covered by solicitor-client privilege, the communications could only be disclosed to reduce a pressing and substantial risk. In this case, the risk related to an identifiable group - prostitutes working Vancouver's

While Henderson J. gave substantial consideration to the duty of confidentiality arising from the "doctor-patient" relationship and to the public safety exception to this duty, the Court of Appeal stated that "the question of professional confidentiality between doctor and patient was not raised in the pleadings and was treated by both counsel before us as a minor issue" (Smith v. Jones (C.A.), supra note 4 at para. 20). The doctor-patient perspective was not addressed by the Supreme Court. The reasoning applicable to solicitor-client privilege, though, would also apply to "care giver"-patient confidentiality. Physicians, psychiatrists, psychologists, nurses, and other health care professionals would all be entitled to disclose confidential information to protect life and bodily integrity.

$133 \quad$ Smith v. Jones, supra note 1 at 239.

iis Ibid. at 231.

IIs Ibid. at 231-32. Major J.'s opinion was correct: respecting Canadian law, see the Honourable J. Sopinka J., S.N. Lederman \& A.W. Bryant, The Law of Evidence in Canada (Toronto: Butterworths, 1992) at 650, 657; E.J. Levy, Examination of Witnesses in Criminal Cases, 3d ed. (Scarborough, Ontario: Carswell, 1994) at 366-67; the Honourable D. Watt J., Watt's Manual of Criminal Evidence, 1998 (Scarborough, Ontario: Carswell, 1998) at 100, 101; D.M. Paciocco \& L. Stuesser, The Law of Evidence (Concord, Ontario: Irwin Law, 1996) at 139; and respecting American law, see Mueller \& Kirkpatrick, supra note 47 at 369; and Hall, supra note 47 at 31314.

116. Smith v. Jones, supra note 1 at 233. The argument is made explicit in the Court of Appeal's decision: "Before us, both counsel agreed that there is no property in a witness, whether lay or expert. It has been held that the expert's opinion, as distinct from his communications with the solicitor who retains him, is not protected by the solicitor/client privilege.... In this case, what is clearly privileged are the communications which passed between the solicitor and the expert, and those between the client and the expert" (Smith v. Jones (C.A.), supra note 4 at para. 24). 
downtown Eastside. The risk was substantial, of great magnitude. The potential victims were at risk of death or serious bodily harm; serial torture and murder were feared. ${ }^{118}$

The "time line," probability, and degree of proof issues were less certain. Jones did turn himself in. Cory J. quite properly pointed out that Jones did not attack anyone during the approximately twelve months that he was at liberty on bail. ${ }^{119}$ Neither did Jones commit any offence while on bail, save the violation of the term of his release. Jones had committed only one offence of violence: there was no evidence of a series of past offences from which the probability of future offences could be inferred. ${ }^{120}$ Dr. Smith, according to Cory J., did not provide evidence that he believed it was probable that Jones would commit another attack in the near future. ${ }^{121}$ The weight of Dr. Smith's concerns was somewhat impaired by the fact that, following the initial contact with defence counsel, he waited some three months before contacting counsel again. ${ }^{122}$

Dr. Smith rehabilitated his concerns, however, by taking it upon himself to contact Jones' counsel and by commencing the action for the declaration. ${ }^{123}$ Furthermore, Jones had admitted to planning torture and murder, with significant attention to method and detail. Dr. Smith had concluded that Jones was, among other things, a sexual sadist. Jones had described the first attack as a "trial run." Jones had already acted out once. Cory J. was impressed by Jones' admission that he had breached his bail conditions by continuing to visit the downtown Eastside "where he knew prostitutes could be found." 24 Cory J. also commented - and this is a somewhat disturbing basis for a judgment - that "common sense would indicate that after Mr. Jones was arrested, and while he was awaiting sentence, he would have been acutely aware of the consequences of his actions." ${ }^{25}$ Jones' failure to act out in his period of liberty was interpreted as evidence of his cleverness rather than as evidence that he was not an immediate danger. Cory J. assumed guilt and a behavioural cover-up. But ignoring this last factor, there was an adequate basis for the disclosure of Jones' dangerousness to the authorities.

The measures Dr. Smith employed to effect disclosure were problematic, although Jones could have little complaint. Dr. Smith asked the courts to decide and did not make the disclosure decision on his own; Jones was kept anonymous throughout the litigation; Dr. Smith did not make public disclosures to the police or prospective victims. Jones was as protected as was possible. Dr. Smith was also protected. $\mathrm{He}$ would not disclose without judicial authorization. This would insulate him from an

Smith v. Jones, supra note 1 at $252,253$.

Ibid. at 253.

Ibid.

Ibid. at 254. In contrast, Henderson J. stated that "[a]n experienced forensic psychiatrist has concluded that it is more likely than not that Mr. Jones will kill someone. Dr. Smith is satisfied that there is an imminent danger to the life or safety of women in the skid row area... " (Smith $\mathbf{v}$. Jones (S.C.), supra note 5 at para. 33).

Smith v. Jones, supra note 1 at 254.

Ibid.

Ibid.

lbid. 
action by Jones. In the result, potential victims were not prejudiced by Dr. Smith's procedure because none were attacked by Jones while he was on bail. Nonetheless, Dr. Smith's procedure did not offer much in the way of protection to Jones' potential victims. An application for a declaration was not necessarily the most rational means of protecting the prostitutes of downtown Eastside Vancouver. As Cory J. wrote, "[a]lthough it is true that this procedure may protect the expert from legal consequences, there may not always be time for such an action." ${ }^{26}$ Neither Cory J. nor Major J. explicitly criticized Dr. Smith's actions.

As discussed above, Cory J. considered the scope of disclosure (subject to Henderson J.'s editing) appropriate. Since the aggravated assault in question was a "trial run" for the further feared attacks, reference to the offence itself in the disclosure was appropriate in the circumstances.

\section{SOME FURTHER ISSUES}

\section{A. What about LaWyers?}

Smith v. Jones concerned a psychiatrist's disclosure of privileged and confidential material. What about lawyers? More precisely, what about Jones' lawyer? Would he or she have been justified in turning Jones in? Not a word on this issue was spoken by Cory or Major JJ. Since, however, the case expressly turned on solicitor-client privilege, it must follow that Jones' defence counsel could have been entitled to inform on Jones. Obviously, defence counsel did not do so, despite having heard Dr. Smith's concerns (and who knows what else from Jones himself). Under the British Columbia Professional Conduct Handbook, defence counsel had a discretion to disclose information about Jones, but was not required to do so: "A lawyer may disclose information received as a result of a solicitor-client relationship if the lawyer has reasonable grounds to believe that the disclosure is necessary to prevent a crime involving death or serious bodily harm to any person."'27 The B.C. ethical rules leave the decision to disclose to the private morality of lawyers. Jones' counsel was not under a duty to disclose, and, in the absence of knowledge of all of the circumstances, we cannot assign fault to Jones' counsel.

We can assign fault to Cory and Major $\mathrm{JJ}$. for their failure to discuss the plight of counsel. Given that the public safety exception must stand, lawyers are left in the uneasy position of being leaky receptacles for client confidences. We might have wished for some judicial expression of empathy for the legal brawler who has committed his or her all to defending accuseds and who now is forcibly reminded that he or she should become an informer; we might have wished for some empathy for the extremely difficult decisions that counsel may be forced to make. We might also have expected some guidance on what lawyers and psychiatrists should tell their clients about confidentiality - "what you tell me will be kept confidential, unless what you tell me is really bad, in which case I may have to turn you in." Of course, privilege and

127 Chapter 5, s. 12 (Smith v. Jones, supra note 1 at 248). 
confidentiality have always laboured under exceptions, so the client relations problem is nothing new. What was new was the opportunity the Supreme Court had to provide guidance to counsel.

\section{B. What abOUT THE EVIDENCE?}

Major J. referred to yet another issue ignored by Cory J.: what of the admissibility of disclosed evidence? Major J. wrote that "nothing in this decision is intended to decide whether any of the privileged communications made between Mr. Jones and Dr. Smith are admissible at any judicial proceedings. Those are issues to be determined by the presiding judge as they arise." 128 On this issue, Cory J. simply mused that "the result [of this case] may well affect the sentence imposed on Mr. Jones." 129

In theory, evidence could be disclosed to potential victims, the Crown, or the police for the purposes of providing warning, but the evidence could be inadmissible at trial. (Relaxed evidential standards in judicial interim release or sentencing proceedings could result in the admissibility of the evidence in those contexts only.) The inadmissibility of publicized "warning evidence" is not unheard of. Newspapers, for example, may publish suspects' criminal records, character evidence about suspects, or details about alleged offences, without that evidence ever finding its way into a judicial record. If the publicized "warning evidence" were not relevant to litigation, it would not be admissible. If it were relevant, its use in court could be resisted on the basis that the privilege is the client's, the client never waived the privilege, and the lawyer in question cannot be forced to disclose the evidence through testimony. The public disclosure by the lawyer would not be taken to have destroyed the privilege, any more than the accidental disclosure of confidential information (by, say, a mis-sent fax) destroys privilege. ${ }^{130}$ Those who received the warning would be in possession of hearsay and arguably should not be permitted to repeat what they were told for the truth of its contents (although the Crown would likely argue that the principled exception to the hearsay rule applies: receipt of the evidence through the recipients of the warning is "necessary" because the lawyer cannot be compelled to testify, and the evidence is "reliable" because of the nature of the information and the circumstances in which it was disclosed). ${ }^{131}$ The evidence could be inadmissible as character evidence, where the accused has not put character into issue or if the evidence fails to meet the standards for the admissibility of "similar fact" evidence. Perhaps Jones' sentencing judge will have sufficient sensitivity to evidential issues to give us some direction on the admissibility of disclosure evidence.

\section{ConClusion}

Smith v. Jones amounts to a first cut at a tough set of issues. The Supreme Court will have to return to the public safety exception to tell us whether disclosure is

Smith v. Jones, supra note 1 at 237.

Ibid. at 256.

Royal Bank of Canada v. Lee and Fishman (1992), 127 A.R. 236 (C.A.).

See R. v. Hawkins and Morin, [1996] 3 S.C.R. 1043 at 1082-87, Lamer C.J.C. and lacobucci J. 
discretionary, mandatory, or mandatory unless there are good reasons for not effecting disclosure; to establish the true basis of privilege; to provide a better account of the aspects of risk assessment; to tell us whether the public safety exception applies to socially disruptive conduct not involving violence; to trace the interconnections between the exception and tort rules; to rule on the admissibility of disclosed evidence; and, generally, to provide better guidance to counsel. Difficulties abound when we give up secrets for lives. 